\title{
A study of somatolactin actions by ectopic expression in transgenic zebrafish larvae
}

\author{
Guohui Wan and King Ming Chan \\ Department of Biochemistry, Faculty of Science, Chinese University of Hong Kong, Sha Tin, N.T., Hong Kong SAR, People's Republic of China \\ (Correspondence should be addressed to K M Chan; Email: kingchan@cuhk.edu.hk)
}

\begin{abstract}
Somatolactin (SL) is a fish-specific hormone that belongs to the prolactin (PRL) and GH family. Recently, two forms of SL, $S L \alpha$ and $S L \beta$, have been found in some species, and may have different actions and functions. To investigate the role of SL in fish growth and metabolism, we generated transgenic fish founders with ectopic expression of SL $\alpha$ and SL $\beta$ to study the physiological functions and actions of these SLs among several marker genes. We fused the cDNAs encoding the precursor SLs in frame to a zebrafish $\beta$-actin gene promoter to generate transgenic zebrafish lines that were coinjected with a green fluorescent protein (GFP) driven by the same promoter. The transgenic zebrafish were selected based on GFP expression and confirmed by genomic PCR, Southern blot analysis, and transgene expression. Investigations into the expression of marker genes in larvae on different pathways using real-time PCR have provided a general understanding of the actions of SLs. This study found that the overexpression of SL $\alpha$ and SL $\beta$ in vivo significantly enhanced the transcription of IGFs, insulin, leptin, sterol regulatory element binding protein 1 , and fatty acid synthase, as well as the expression level of vitellogenin and proopiomelanocortin, while causing reduced levels of catalase and glutathione $S$-transferase in the larvae of transgenic zebrafish.
\end{abstract}

Journal of Molecular Endocrinology (2010) 45, 301-315

\section{Introduction}

Somatolactin (SL) is a recently discovered glycoprotein hormone in fish of GH/prolactin (PRL) superfamily, with significant structural homology in all fish taxa studied to date (Ono et al. 1990, Rand-Weaver et al. 1991, 1992, Chen et al. 1994). According to sequence comparisons, it is generally believed that SL and PRL evolved from a common ancestral gene related to $\mathrm{GH}$ with two successive rounds of gene duplication before the divergence between vertebrates and invertebrates (Chen et al. 1994, Fukamachi \& Meyer 2007). However, the $S L$ gene is not found in tetrapods and might have been lost during the evolution of early land vertebrates (Fukamachi \& Meyer 2007). Fish SL is mainly expressed in the pars intermedia of the pituitary gland and distinct from proopiomelanocortin (POMC)-producing cells (Kaneko 1996); hence, it should have physiological actions different from those of GH and PRL. In addition, despite the conserved helical bundles, the number of disulfide bonds (6 or 7 ) is different from that found in GH and PRL (4), and the low sequence identity found between SL and GH $(50-60 \%)$ also suggests that they have dissimilar functions in fish (Chen et al. 1994, Fukamachi \& Meyer 2007).

Two isoforms of SL, SL $\alpha$ and SL $\beta$, have been identified in zebrafish (Zhu et al. 2004) and grass carp (Jiang et al. 2008), and phylogenetic analyses suggest that they are paralogs that result from an ancient duplication of $S L$ genes in ray-finned fish probably related to reproduction (Planas et al. 1992, Chen et al. 1994, Yang \& Chen 2003). The tertiary structures of these two SLs may be different because there is an extra third cysteine in SL $\alpha$, and they share only $60 \%$ sequence identity within the same species (Jiang et al. 2008). Therefore, it would be of interest to know whether the actions and functions of these two SLs differ. The main physiological function of the $S L$ gene remains a matter of debate, but it is likely that SL is involved in multiple and even overlapping functions with other members of the GH/PRL family. Recent studies suggest that SLs are involved in steroidogenesis and reproductive maturation (Planas et al. 1992, Rand-Weaver et al. 1992, Olivereau \& Rand-Weaver 1994, Johnson et al. 1997), acid-base balance (Kakizawa et al. 1996), background adaptation (Kakizawa et al. 1995, Zhu \& Thomas 1995), immune function (Calduch-Giner et al. 1998), energy mobilization and stress (Rand-Weaver et al. 1993), lipid metabolism and pigmentation (Zhu \& Thomas 1997, Fukamachi et al. 2004, 2005, 2009), and the regulation of chromatophores (Zhu \& Thomas 1995, 1996, 1997). The recent discovery of an SL-deficient mutant in medaka (Oryzias latipes) (color interfere, ci) indicated that SL might function in the proliferation and morphogenesis of epidermal chromatophores, body color regulation, or cortisol secretion in vivo (Fukamachi et al. 2005, 
2006, 2009). The gene silencing of SLs in zebrafish (Danio rerio) by antisense morpholino oligonucleotides during embryonic development, however, only showed their different effects on the delay in swim bladder inflation (Zhu et al. 2007).

The presence of two distinct GH receptors (GHRs), GHR clade 1 and GHR clade 2, has been detected in several teleost species (Fukamachi et al. 2005, Jiao et al. 2006, Pierce et al. 2007, Benedet et al. 2008), and phylogenetic analyses of salmon GHRs suggest that GHR clade 1 is an SL receptor (SLR), whereas GHR clade 2 is the actual GHR (Benedet $e t$ al. 2008). A recent study showed that SL could act as a novel regulator of insulin-like growth factor $(I G F)$ gene expression in fish (Wan et al. 2009), which suggests that SL may exert its effects indirectly by way of the GH/IGF axis. Whether the actions of SL are on the GHR or SLR remains to be investigated; however, SL and GH may have overlapping functions. Among mammals are a large number of paralogous genes (e.g. there are 26 PRL-related genes in rats and mice), and the non-classical actions of these ligands are mediated through neither the PRL nor the GHR (Ain et al. 2004, Green 2004). Therefore, it is believed that the functional study of SLs by knockdown assay in embryos has been impaired by the compensational effects of other genes because of redundant functions in the GH/PRL family. Nevertheless, the overexpression of SLs in vivo can reveal a gain of function that may be unrecognized by targeted mutational analysis because of functional redundancy.

To study the actions of two closely related $S L$ genes by ectopic expression in transgenic zebrafish, we cloned cDNAs encoding the precursor SLs in frame to a zebrafish $\beta$-actin $(\beta A)$ gene promoter that would overexpress $S L$ genes ubiquitously to generate transgenic zebrafish lines coinjected with a green fluorescent protein (GFP) driven by the same promoter. Larvae of these transgenic fish founders were used for the analysis of marker gene expression in growth, development, metabolism, reproduction, pigmentation, and the antioxidant defence system to reveal the main functions of SLs.

\section{Materials and methods}

\section{Zebrafish}

Zebrafish were obtained from a local pet shop. This is a local strain of zebrafish derived from India that is used for many experiments. The protocols for rearing and keeping zebrafish were adopted from Westerfield (1995). A license (09-142 in DH/HA\&P/8/2/1 Pt.6) to conduct experiments was obtained from the Department of Health, Government of the Hong Kong Special Administrative Region, China.

\section{DNA constructs}

Genomic DNA samples were purified from whole zebrafish by grinding in liquid nitrogen and further digestion with proteinase $\mathrm{K}$ and phenol-chloroform extraction (Westerfield 1995). The zebrafish $\beta A$ gene promoter (Liu et al. 1990, 1991) was amplified using the Expand High Fidelity PCR System (Roche). Purified zebrafish genomic DNA (200 ng) was mixed with $5 \mu \mathrm{l}$ of $10 \times$ Expand High Fidelity buffer, $15 \mathrm{mM}$ of $\mathrm{MgCl}_{2}$, $1.5 \mu \mathrm{l}$ of $10 \mu \mathrm{M} \mathrm{z} \beta \mathrm{A}$ forward primer (5'-GGGGTACC AGTAATGCAGCAGCGTGAAG-3' $\left.{ }^{\prime}\right), 1 \cdot 5 \mu \mathrm{l}$ of $10 \mu \mathrm{M}$ z $\beta A$ reverse primer (5'-TCCCCCGGGGGCTGTAGGGAAAAAAAGCG- $\left.3^{\prime}\right), 1 \mu \mathrm{l}$ of $10 \mathrm{mM}$ of dNTP mix, and $0 \cdot 75 \mu \mathrm{l}$ of Expand High Fidelity Enzyme Mix (Applied Biosystems, Foster City, CA, USA). Finally, distilled water was added to increase the reaction volume to $50 \mu \mathrm{l}$. The DNA primers were designed with enzyme sites (KpnI and SmaI) for cloning into pGL3-Basic vector (Promega) according to the zebrafish genomic sequence in the GenBank database of the National Center for Biotechnology Information (NCBI) (accession no. AL928650). PCR was performed on the TaKaRa PCR Thermal Cycler Dice with the following conditions: one cycle at $94{ }^{\circ} \mathrm{C}$ for $2 \mathrm{~min}, 30$ cycles at $94{ }^{\circ} \mathrm{C}$ for $30 \mathrm{~s}$, $60{ }^{\circ} \mathrm{C}$ for $30 \mathrm{~s}$, and $72{ }^{\circ} \mathrm{C}$ for $3 \mathrm{~min}$, followed by one cycle of $72{ }^{\circ} \mathrm{C}$ for $7 \mathrm{~min}$. The gel-extracted PCR product was cloned into the pGEM-T Easy Vector System (Promega) and sent to a commercial DNA sequence service, Tech-Dragon, for nucleotide sequence determination.

The cDNA obtained by reverse transcriptase (Promega) was used as a template for zebrafish $S L \alpha, S L \beta$, and $G H$ gene amplification using the following specific primer sets:

\section{zSL $\alpha \mathrm{F}$ ( $5^{\prime}$-ATGAACACAGTTAAAGTTCTGCAGG-3 ${ }^{\prime}$ ) and zSL $\alpha \mathrm{R}$ (5'-CTATTATTGGGGCAGGCAGGTGAGTT- $3^{\prime}$ ); zSLBF (5'-ATGATGAAGAAAGCTACAGG-3') and zSLBR (5'-CTATTAGAAGAGGGAGCAGTTTTCG $\left.3^{\prime}\right)$; zGHF ( $5^{\prime}$-ATGGCTAGAGCATTGGTGCT- $3^{\prime}$ ) and zGHR (5'-CTATTACAGGGTACAGTTGGAATCCA-3' ${ }^{\prime}$ ).}

The primers were designed according to the zebrafish database of the NCBI (accession no. NM_001037706 for SL $\alpha$, NM_001037674 for SL $\beta$, and BC116501 for $\mathrm{GH})$. GFP was amplified from a commercial vector, phrGFP II-1 (Stratagene, La Jolla, CA, USA).

The $\beta A$ gene promoter was cloned into the pGL3-Basic vector (Promega) to study the promoter activity that drives the firefly luciferase reporter gene. The cDNAs of zebrafish SL $\alpha$, SL $\beta$, GH, and humanized renilla GFP (hrGFP) were respectively replaced with luciferase reporter gene, and the hormone overexpression constructs were linearized, containing only the promoter element, hormone cDNA, and polyA signal elements, with plasmid and its antibiotic resistance gene removed (Fig. 1). 
(a)

$\mathrm{z} \beta$-Actin gene promoter

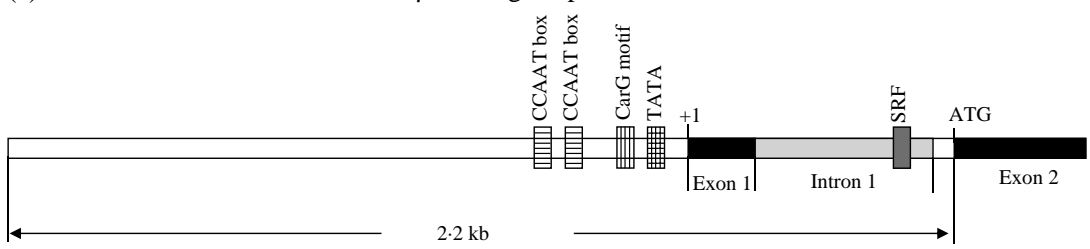

(b)

$\mathrm{z} \beta \operatorname{AzSL} \alpha(3 \cdot 2 \mathrm{~kb})$

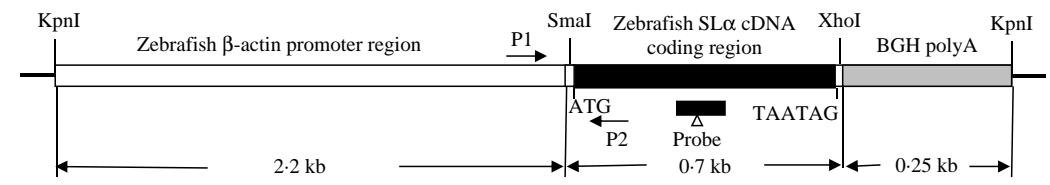

(c)

$\mathrm{z} \beta \operatorname{AzSL} \beta(3 \cdot 2 \mathrm{~kb})$

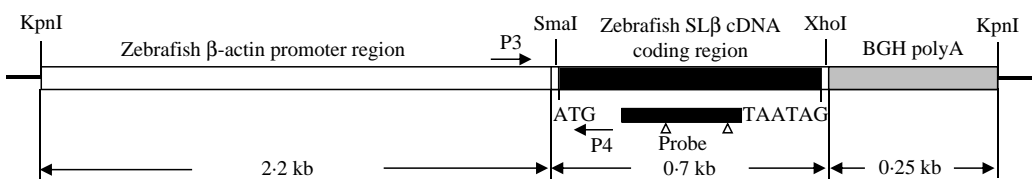

(d)

zßAzGH (3.2 kb)

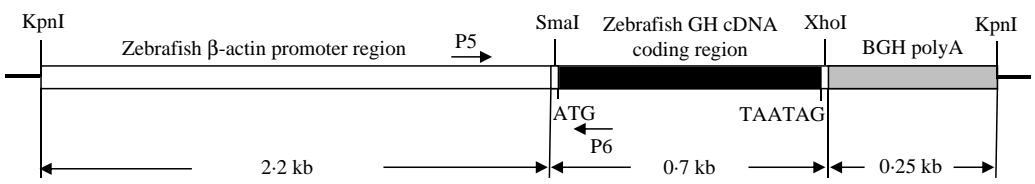

(e)

zßAhrGFP $(3 \cdot 2 \mathrm{~kb})$

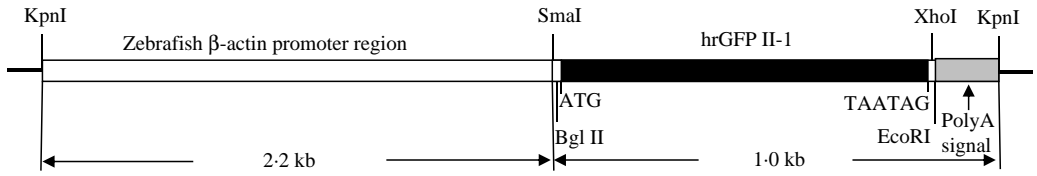

Figure 1 Schematic diagrams of hormone overexpression vectors. (a) A total of $2.2 \mathrm{~kb}$ region of zebrafish $\beta$-actin gene promoter before translation start codon (ATG) was isolated for the hormone overexpression constructs, containing some conserved elements, e.g. SRF element in intron 1 , which can enhance the activity of $\beta$-actin gene promoter. $(b-d)$ The $z \beta A z S L \alpha, z \beta A z S L \beta$, and $z \beta A z G H$ constructs isolated from the plasmids after digestion with Kpnl and used for microinjection, showing some restriction sites for transgene detection. Primers P1 and P2, P3 and P4, and P5 and P6 were used in the genomic DNA PCR reactions to identify transgenic fish for $z \beta A z S L \alpha, z \beta A z S L \beta$, and $z \beta A z G H$ respectively. Probes in $z \beta A z S L \alpha$ and $z \beta A z S L \beta$ were used in Southern blot analysis for further confirmation of transgenic fish, while $\Delta$ indicates intron in the genomic DNA of wild-type fish. (e) The z $\beta A$ hrGFP construct isolated from the plasmid after digestion with Kpnl and used as a coinjection strategy for positive GFP signal detection.

\section{Generation of transgenic zebrafish}

Adult zebrafish were reared in a closed water circulation system at $28^{\circ} \mathrm{C}$ under a controlled photoperiod of $14 \mathrm{~h}$ light: $10 \mathrm{~h}$ darkness cycle (Westerfield 1995). An egg collection device was placed into a tank of fish at the beginning of the light cycle. Eggs were collected $\sim 20$ min after being laid (one- to two-cell stage) and coinjected with the linearized vectors dissolved in $0.25 \%$ phenol red in $0 \cdot 1 \mathrm{M}$ Tris-HCl (z $\beta A z S L \alpha$ and z $\beta$ AhrGFP; z $\beta$ AzSL $\beta$ and z $\beta$ AhrGFP; $z \beta A z G H$ and $z \beta A h r G F P)$ using the PV820 Pneumatic PicoPump (World Precision Instruments; Chong \& Vielkind 1989, Hamada et al. 1998). Approximately, $500 \mathrm{pl}$ of DNA solution represented a final number of $10^{6}$ copies of each transgene per injected embryo (Zhu et al. 1985). The microinjection needles were made from Narishige GD-1 glass capillaries using the MODEL P-97 microelectrode puller (Sutter Instrument Co., Novato, CA, USA; 
Chong \& Vielkind 1989). The injected embryos were incubated at $28^{\circ} \mathrm{C}$ (Chong \& Vielkind 1989). GFP expression was analyzed $24 \mathrm{~h}$ after fertilization using a Leica DM1L fluorescence microscope with a Leica filter set $($ excitation $=485 \mathrm{~nm}$; emission $=520 \mathrm{~nm})$, and pictures were taken using the Leica DFC420 digital camera system (shown in Fig. 2). Mosaicism in the first transgenic generation $\left(\mathrm{G}_{0}\right)$ was classified according to the GFP expression patterns as follows: weak, a few cells expressing GFP; moderate, $<50 \%$ of the body expressing GFP; or strong, more than $50 \%$ of the body expressing GFP (Gibbs \& Schmale 2000). For the generation of stable transgenic lines, the founders were raised to sexual maturity. Transgenic screening was performed by crosses with wild-type (WT) zebrafish. At least 100 embryos from each founder were examined for GFP fluorescence.

\section{Investigation of transgenes}

Genomic DNA was isolated from $\mathrm{G}_{0}$ and $\mathrm{G}_{1}$ transgenic fish larvae as mentioned above to confirm the positive transgenes by PCR and Southern blotting. The following primers were used for PCR analysis of the transgenes:

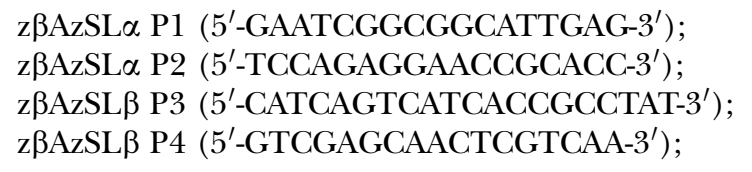

zßAzGH P5 (5'-GAATCGGCGGCATTGAG-3'); and zßAzGH P6 (5'-AAGACGAGCCCATCTTG-3').

PCR was carried out in a $25 \mu \mathrm{l}$ volume containing $25 \mathrm{pM}$ of each primer, $1 \mathrm{mM}$ of each dNTP, and 1 unit of Expand High Fidelity Enzyme (Applied Biosystems) for 35 cycles. Each cycle included $1 \mathrm{~min}$ at $94^{\circ} \mathrm{C}, 30 \mathrm{~s}$ at $60{ }^{\circ} \mathrm{C}$, and $1 \mathrm{~min}$ at $72^{\circ} \mathrm{C}$.

The probes for Southern blot analysis were amplified from the hormone overexpression constructs using the following primers:

\section{zßAzSL $\alpha$ F: 5'-CCCATCCCAACATCCAAGA-3'; zßAzSL $\alpha$ R: 5'-ATACAGCAGCGGCTCCATC-3'; \\ zßAzSL $\beta$ F: 5'-GCTCGACTTATTCGGAGGTATG-3'; and zßAzSL $\beta$ R: 5'-CCAAGCCTCCTTCACCC-3'.}

Double-stranded oligonucleotide probes, z $\beta$ AzSL $\alpha-$ $102 \mathrm{bp}$ and z $\beta A z S L \beta-308 \mathrm{bp}$ ( $\Delta$ in the probes indicated intron in the genomic DNA of the WT fish, which is shown in Fig. 1), were end labeled with digoxigenin (DIG)-11-ddUTP using Terminal transferase (Roche). Purified genomic DNA ( $5 \mu \mathrm{g})$ was digested with EcoRI or SmaI and XhoI overnight, resolved by electrophoresis in a $0.8 \%$ agarose gel, and blotted onto a nylon membrane (Immobilon-N; Millipore, Billerica, MA, USA) using an electroblotting apparatus (TE70 ECL Semi-Dry Transfer Unit, Amersham) according to the manufacturer's instructions. The DNA was fixed onto the membrane by cross-linking it with a transilluminator, and prehybridized in a solution containing $5 \times \mathrm{SSC}$
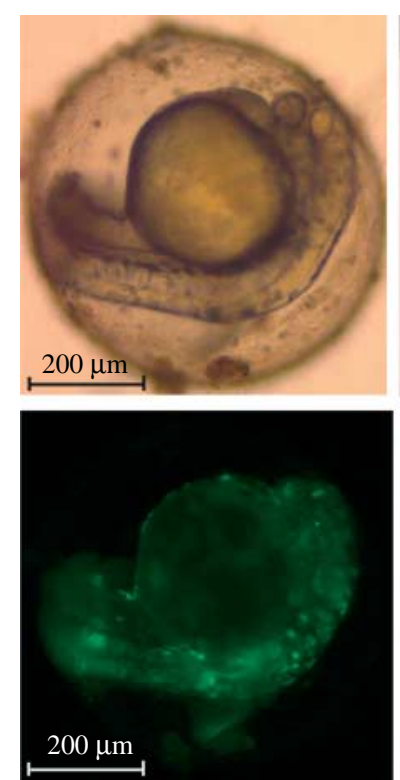

$30 \mathrm{~h}$
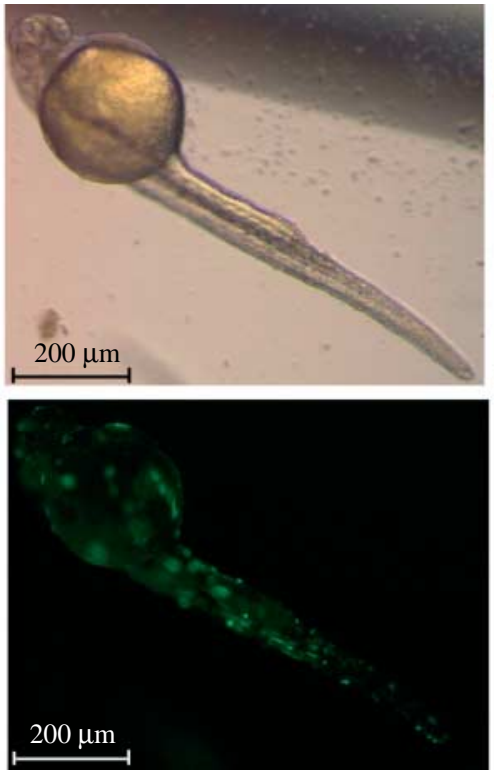

3 days
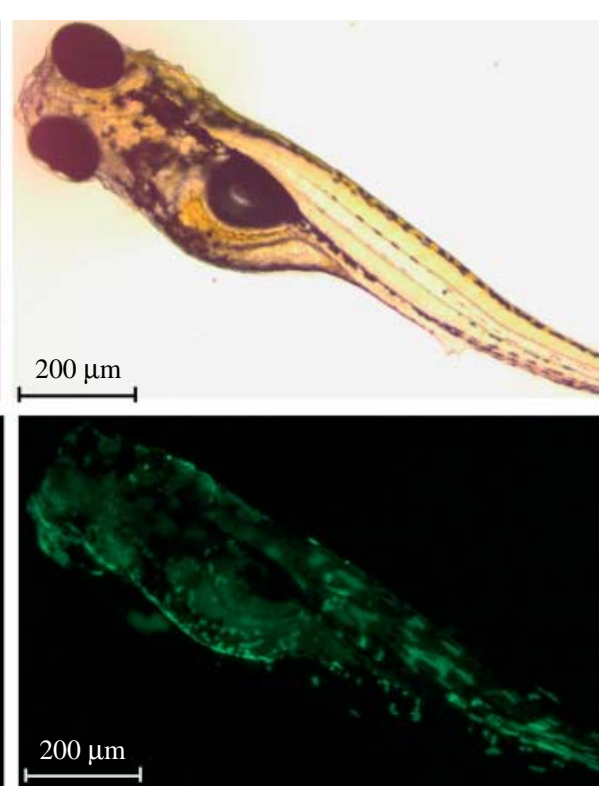

1 week

Figure 2 Investigation of GFP expression in transgenic zebrafish. GFP expression was driven by $\beta$-actin gene promoter to evaluate mosaicism in transgenic zebrafish with hormone (SL $\alpha, \operatorname{SL} \beta$, and $\mathrm{GH}$ ) overexpression in the coinjection strategy. Excitation $=485 \mathrm{~nm}$; Emission $=520 \mathrm{~nm}$. 
(3 $\mathrm{M} \mathrm{NaCl}$ and $0 \cdot 3 \mathrm{M}$ trisodium citrate, $\mathrm{pH} 8 \cdot 0$ ), $1 \% \mathrm{SDS}$, $5 \times$ blocking reaction (Roche), $50 \%$ (v/v) formamide, and denatured salmon sperm DNA at $68^{\circ} \mathrm{C}$ for $4 \mathrm{~h}$. The prehybridization solution was then removed, and a fresh hybridization solution $(5 \times \mathrm{SSC}, 1 \% \mathrm{SDS}$, $5 \times$ blocking reaction, and $50 \%$ (v/v) formamide) containing the denatured DIG-labeled DNA probe (about $25 \mathrm{ng} / \mathrm{ml}$ ) was added and incubated at $68^{\circ} \mathrm{C}$ overnight. The hybridized membrane was washed first in $2 \times \mathrm{SSC}, 1 \% \mathrm{SDS}$ at $25^{\circ} \mathrm{C}$ with constant agitation for $5 \mathrm{~min}$, and $0.5 \times \mathrm{SSC}, 0 \cdot 1 \% \mathrm{SDS}$ at $68^{\circ} \mathrm{C}$ under constant agitation for $15 \mathrm{~min}$. After the immunological detection of the DIG-11-ddUTP, positive signals were detected using FUJI X-ray film for autoradiography.

\section{Rearing of larvae and growth analysis}

Transgenic and non-transgenic fish were reared until 6 months of age in a closed circulation water system composed of 15-1 tanks. Triplicate samples were collected from each genetic group (SL $\alpha$-transgenic $\mathrm{G}_{0}$, SL $\beta$-transgenic $\mathrm{G}_{0}$, and GH-transgenic $\mathrm{G}_{0}$ ), with twenty fish each. Water quality was monitored once a day, and temperature, $\mathrm{pH}$, nitrogenous compounds, and photoperiod were maintained according to zebrafish requirements (Chong \& Vielkind 1989, Westerfield 1995, Gibbs \& Schmale 2000). The fish were fed a high-quality commercial fish diet (ZM Systems, Winchester, UK): all fry were fed with infusoria grade ZM-000 $(30-50 \mu \mathrm{m}, 52 \%$ protein) at week $1, \mathrm{ZM}-100(80-200 \mu \mathrm{m}, 55 \%$ protein $)$ at week $2, \mathrm{ZM}-200(150-300 \mu \mathrm{m}, 60 \%$ protein $)$ at weeks 3-5, and Mediaquafish Guppy Food (300-500 $\mu \mathrm{m}, 48 \%$ protein, Japan) together with freshly hatched brine shrimp (Brine Shrimp Direct, Ogden, UT, USA) from week 6 on. In all situations, the food was completely consumed within $10 \mathrm{~min}$. After the first month, the fish were anesthetized (Tricaine, $0 \cdot 1 \mathrm{mg} / \mathrm{ml}$ ) and weighed every 2 weeks to maintain the percentage of food by biomass in each tank. At the end of the experiment, the mean weight was compared among the three test groups. In addition, the total length of individual fish was measured, and the condition factor $(K)$ was calculated using the formula $K=\left(W \cdot L^{-3}\right) \times 10^{3}$, where $W$ is the mass in milligrams and $L$ is the total length in millimeters.

\section{Quantification of mRNA levels using real-time PCR}

Using ABI Primer Express software (Applied Biosystems), specific primers (Table 1) for zebrafish $\beta A$ (AF057040), SL $\alpha$ (AY376857), SL $\beta$ (AJ867249), GH (AJ937858), PRL (NM_181437), IGF1 (NM_131825), IGF2a (NM_131433), IGF2b (NM_001001815), IGF3 (EU272146), leptin (LEP, NM_001128576), sterol regulatory element binding protein 1 (SREBP1, DQ836065), SREBP2 (ENSDARG00000063438), fatty acid synthase (FAS, XM_682295), acetyl-coA carboxylase 2 (ACC2, XM_678989), vitellogenin (VTG, NM_001044897), POMC (NM_181438), phosphoenolpyruvate carboxykinase (PEPCK, NM_214751), insulin (INS, NM_131056), catalase (CAT, AF170069), and glutathione $S$-transferase (GST, AB194127) were designed to span two exons at the intron-exon junction to prevent the primers from binding to the genomic DNA sequences amplifying the contaminated DNA in the samples, and hence minimize genomic contamination in reverse transcription-PCR (Table 1).

Table 1 Nucleotide sequences of gene-specific primers for real-time PCR in zebrafish

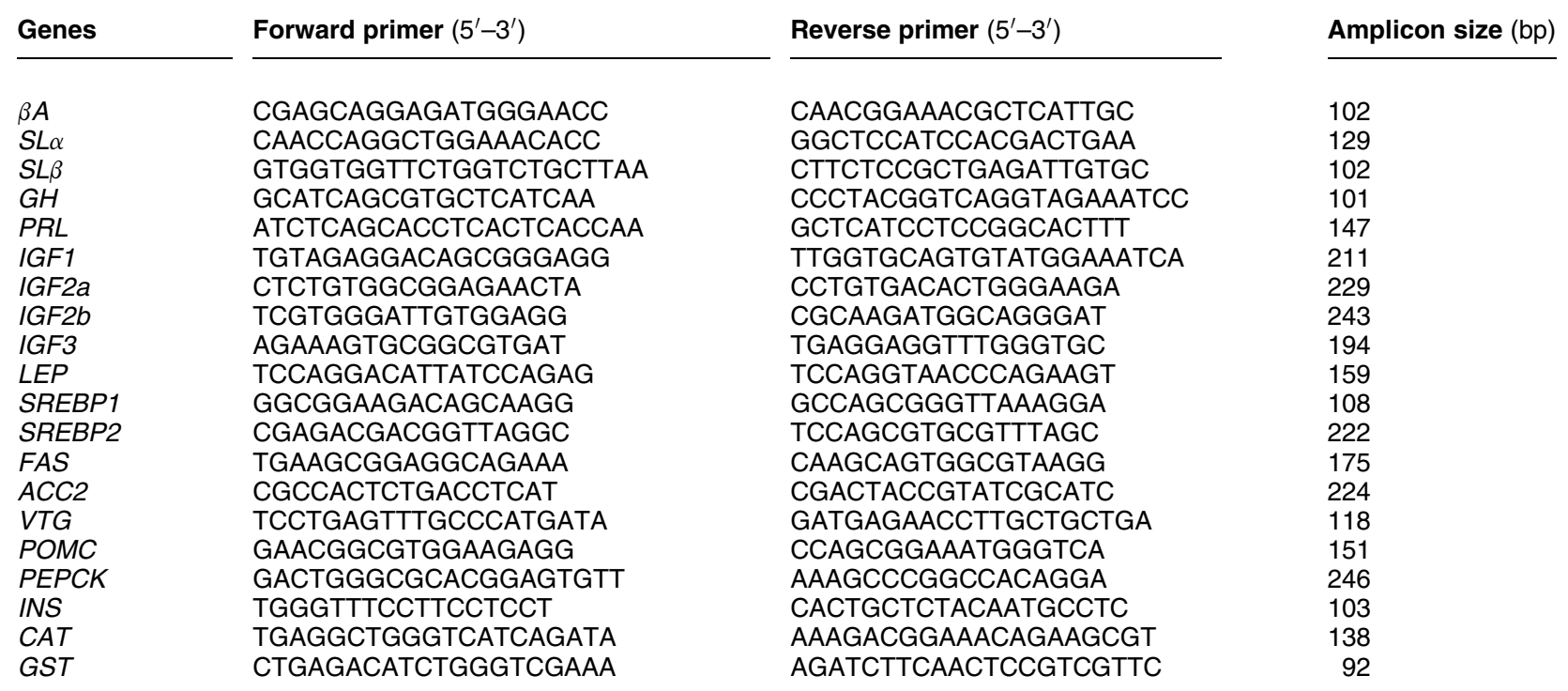


Transgenic larvae and non-transgenic larvae $(N=6)$ at week 5 were sampled to grind in liquid nitrogen. TRIzol reagent (Invitrogen) was used for total RNA extraction. Then, DNase treatment was performed with RNase-free DNase (Takara, Kyoto, Japan). Reverse Transcriptase (Promega) was used for cDNA synthesis. To perform real-time PCR, a reaction mixture was set up in a $0.2 \mathrm{ml}$ clear thin-walled, optical-grade PCR tube that contained 12.5 $\mu$ l Brilliant SYBR Green QPCR master mix (Applied Biosystems), $0.5 \mu \mathrm{l}$ of forward primer $(10 \mu \mathrm{M}), 0.5 \mu \mathrm{l}$ of reverse primer $(10 \mu \mathrm{M})$, $2 \mu \mathrm{l}$ cDNA template, and $9 \cdot 5 \mu \mathrm{l}$ nuclease-free water for a final volume of $25 \mu \mathrm{l}$.

Real-time quantitative PCR was carried out on the ABI 7700 detection system (Applied Biosystems). The PCR cycles were 1 cycle at $95^{\circ} \mathrm{C}$ for $10 \mathrm{~min}, 40$ cycles at $95^{\circ} \mathrm{C}$ for $30 \mathrm{~s}, 58^{\circ} \mathrm{C}$ for $30 \mathrm{~s}$, and $72^{\circ} \mathrm{C}$ for $1 \mathrm{~min}$. All PCR assays were performed in triplicate. The fold inductions of candidate genes were determined by dividing the relative mRNA levels of transgenic samples by those of the control samples, all normalized with the level of $z \beta A$. All of the data were analyzed using one-way ANOVA and Tukey's multiple comparison tests with a $95 \%$ confidence level on GraphPad Prism 5.

\section{Results}

\section{Production of SL-transgenic fish}

From a local strain of zebrafish, a $2 \cdot 2 \mathrm{~kb}$ region of zebrafish $\beta A$ gene promoter was isolated using genomic PCR. Potential transcription factor binding sites that may be involved in regulating the $\beta A$ gene promoter were found (Fig. 1a). SL $\alpha$-transgenic and SL $\beta$-transgenic zebrafish were produced by the coinjection of the transgenes $z \beta A z S L \alpha$ and $z \beta A h r G F P$, and $z \beta A z S L \beta$ and $z \beta A h r G F P$ respectively in an equimolar ratio (1:1), using one-cell embryos (Fig. 1).

At the time of assessment by fluorescence microscopy (Fig. 2), which was 1 week after fertilization, the survival rate of the untreated fish embryos was observed and recorded as 786 out of $1120(70 \cdot 2 \%)$, whereas the survival rate of the microinjected embryos was 352 out of 1100 (32\%) for the SL $\alpha$-transgenic ones and 343 out of $1300(26 \cdot 4 \%)$ for the SL $\beta$-transgenic ones respectively. Among the 352 SL $\alpha$-transgenic embryos, 118 $(33.5 \%)$ were classified as GFP negative (no expression), $111(31.5 \%)$ as weakly GFP positive, 89 $(25 \cdot 3 \%)$ as moderately GFP positive, and $34(9 \cdot 7 \%)$ as strongly GFP positive. Among the 343 SL $\beta$-transgenic embryos, $127(37 \%)$ were classified as GFP negative (no expression), $135(39 \cdot 4 \%)$ as weak GFP positive, 62 $(18 \cdot 1 \%)$ as moderately GFP positive, and $19(5 \cdot 5 \%)$ as strongly GFP positive. GH-transgenic zebrafish were used as positive controls by coinjecting the transgenes $z \beta A z G H$ and $z \beta A h r G F P$. The strongly GFP-positive samples were collected and used for further analysis.

\section{Identification of transgenic zebrafish by genomic DNA PCR and Southern blot}

Genomic DNA was extracted from the samples of 5 -week-old transgenic fish with strong GFP expression to determine the presence of the $z \beta A z S L \alpha, z \beta A z S L \beta$, and $z \beta A z G H$ transgenes. In the PCR analysis, a $299 \mathrm{bp}$ fragment was generated from SL $\alpha$-transgenic $\mathrm{G}_{0}$ zebrafish \#14 and \#28 using primers P1 and P2, and a $298 \mathrm{bp}$ fragment was generated from SL $\beta$-transgenic $G_{0}$ zebrafish \#5 and \#11 using primers P3 and P4 (Fig. 3a). A $673 \mathrm{bp}$ fragment was detected in the positive control
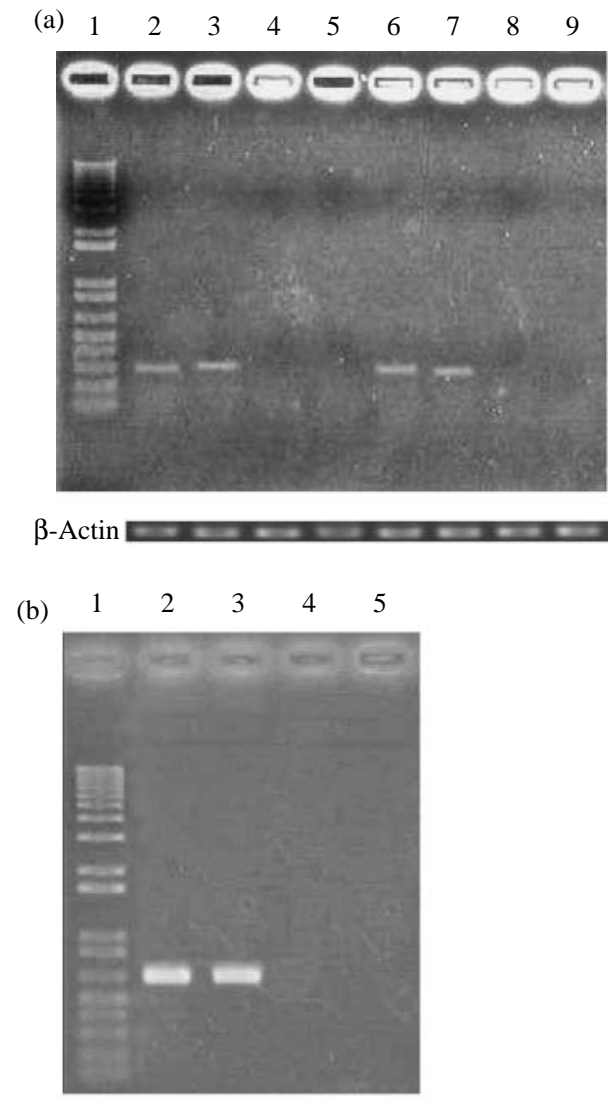

$\beta$-Actin

Figure 3 Identification of transgenic fish by genomic DNA PCR. (a) Positive transgenic fish were identified using primers $\mathrm{P} 1$ and P2 for SL $\alpha$ (299 bp) and primers P3 and P4 for SL $\beta$ (298 bp). Lane 1, $1 \mathrm{~kb}$ Plus DNA Ladder (Invitrogen); lanes 2 and $3, \mathrm{SL} \alpha-$ transgenic samples \#14 and \#28; lanes 6 and 7, SL $\beta$-transgenic samples \#5 and \#11; lanes 4 and 5 and lanes 8 and 9, nontransgenic samples. (b) Positive transgenic fish were identified using primers $\mathrm{P} 5$ and $\mathrm{P} 6$ for $\mathrm{GH}$ (673 bp). Lane 1, $1 \mathrm{~kb}$ Plus DNA Ladder (Invitrogen); lanes 2 and 3, GH-transgenic samples \#25 and \#26; lanes 4 and 5, non-transgenic samples. 
(a)

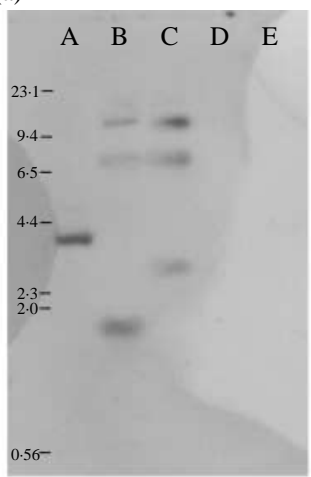

(c)

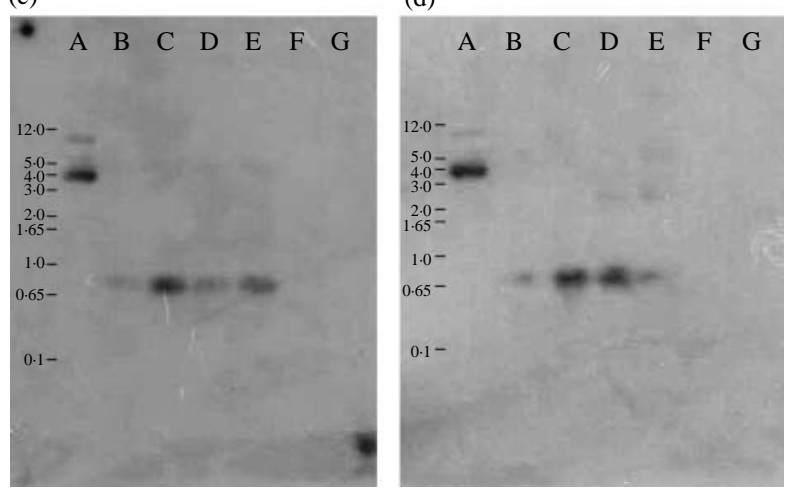

Figure 4 Southern blot analysis of genomic DNA samples isolated from SL-transgenic zebrafish. (a) Genomic DNA from SL $\alpha$ transgenic lines digested with EcoRI. Lane A, z $\beta A z S L \alpha$ plasmid (uncut control); lanes B and C, SL $\alpha$-transgenic $\mathrm{G}_{0}$ samples \#14 and \#28; lanes $D$ and $E$, non-transgenic samples. (b) Genomic DNA from SL $\beta$-transgenic lines digested with EcoRI. Lane A, $z \beta A z S L \beta$ plasmid (uncut control); lanes $B$ and $C, S L \beta$-transgenic $\mathrm{G}_{0}$ samples \#5 and \#11; lanes $\mathrm{D}$ and $\mathrm{E}$, non-transgenic samples. (c) Genomic DNA from SL $\alpha$-transgenic lines digested with Smal and Xhol. Lane A, z $\beta A z S L \alpha$ plasmid (uncut control); lanes $B$ and $C, S L \alpha$-transgenic $G_{0}$ samples \#14 and \#28; lanes $D$ and $E$, $S L \alpha$-transgenic $G_{1}$ samples \#57 and \#60; lanes $F$ and $G$, nontransgenic samples. (d) Genomic DNA from SL $\beta$-transgenic lines digested with Smal and Xhol. Lane A, z $\beta A z S L \beta$ plasmid (uncut control); lanes $B$ and $C, S L \beta$-transgenic $G_{0}$ samples \#5 and \#11; lanes $D$ and $E, S L \beta$-transgenic $G_{1}$ samples \#37 and \#38; lanes $F$ and $G$, non-transgenic samples. *The specific DIG-labeled probes used in the SL $\alpha$-transgenic and SL $\beta$-transgenic lines are shown in the $z \beta A z S L \alpha$ and $z \beta A z S L \beta$ constructs respectively (Fig. 1).

samples (GH-transgenic $\mathrm{G}_{0}$ zebrafish \#25 and \#26) using primers P5 and P6 (Fig. 3b). Southern blot analysis revealed that three bands were present separately in SL $\alpha$-transgenic $\mathrm{G}_{0}$ zebrafish \#14 and \#28 (Fig. 4a), one band in SL $\beta$-transgenic $G_{0}$ zebrafish \#5 and two bands in SL $\alpha$-transgenic $\mathrm{G}_{0}$ zebrafish \#11 in the digestion of EcoRI (Fig. 4b). It is suggested that the transgene $z \beta A z S L \alpha$ was integrated into three different sites in the genome of SL $\alpha$-transgenic $\mathrm{G}_{0}$ zebrafish \#14 and \#28, and the transgene $z \beta A z S L \beta$ was integrated into only one site in SL $\beta$-transgenic $G_{0}$ zebrafish \#5 and two sites in SL $\beta$-transgenic $\mathrm{G}_{0}$ zebrafish \#11. Simultaneously, in the digestion of SmaI and XhoI, which cut through the whole length of SL $\alpha$ and SL $\beta$ cDNA in the transgenes, a $700 \mathrm{bp}$ band was found as expected and detected in both the SL-transgenic $G_{0}$ and $G_{1}$ samples (Fig. 4c and $d$ ). All of these data suggest that the transgenes $z \beta A z S L \alpha, z \beta A z S L \beta$, and $z \beta A z G H$ were integrated into the host genome, consistent with hrGFP expression.

\section{Growth analysis of SL-transgenic $G_{0}$ founders}

The SL-transgenic $\mathrm{G}_{0}$ founders did not grow faster or bigger than the non-transgenic fish; however, a special stripe phenotype was found in the SL $\alpha$-transgenic $G_{0}$ line (Fig. 5). At the end of the growth experiment, the SL $\alpha$-transgenic $G_{0}$ fish reached a final average body weight of $421 \cdot 1 \pm 78.3 \mathrm{mg}$; their SL $\beta$-transgenic $G_{0}$ siblings reached a final average body weight of $443.4 \pm 82.6 \mathrm{mg}$; and their GH-transgenic $\mathrm{G}_{0}$ siblings reached a final average body weight of $542 \cdot 9$ $\pm 103.7 \mathrm{mg}$. The transgenic fish all show higher body mass in comparison with their non-transgenic siblings $(328 \cdot 6 \pm 68 \cdot 2 \mathrm{mg}$; Fig. 6a). The SL subtypes had a similar growth enhancement effect, which was less than that of GH. The condition factors calculated for all transgenic and non-transgenic zebrafish used in this experiment are shown in Fig. 6b. However, the $K$ values of the transgenic and the non-transgenic fish show no significant difference.

\section{Assessment of the physiological effects of SL among SL-transgenic $G_{0}$ founders}

To find out whether the overexpression of hormones would affect the expression of their family members, the endogenous mRNA levels of $S L \alpha, S L \beta$, and $G H$ genes in 5-week-old transgenic zebrafish were investigated (Fig. 7). The results show a $24 \cdot 3$-fold induction of SL $\alpha$ in the SL $\alpha$-transgenic fish without obvious up- or down-regulation of other members in the GH family.

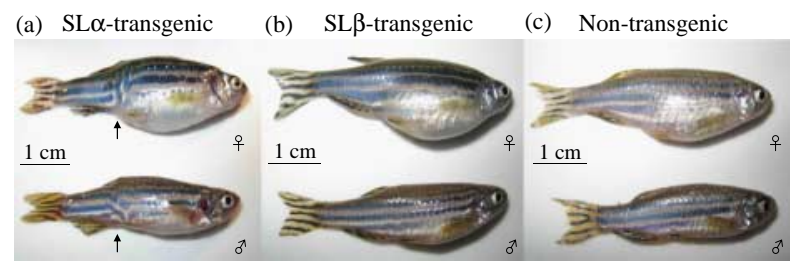

Figure 5 Photographs showing 6-month-old zebrafish (Danio rerio) of transgenic zebrafish. (a) $S L \alpha$-transgenic $G_{0}$ fish;

(b) SL $\beta$-transgenic $G_{0}$ fish; (c) non-transgenic fish. The fish are a representative sample of the mean size of the three groups.

The arrow indicates the special stripe phenotype of the

$\mathrm{SL} \alpha$-transgenic $\mathrm{G}_{0}$ fish. Full color version of this figure available via http://dx.doi.org/10.1677/JME-09-0173. 

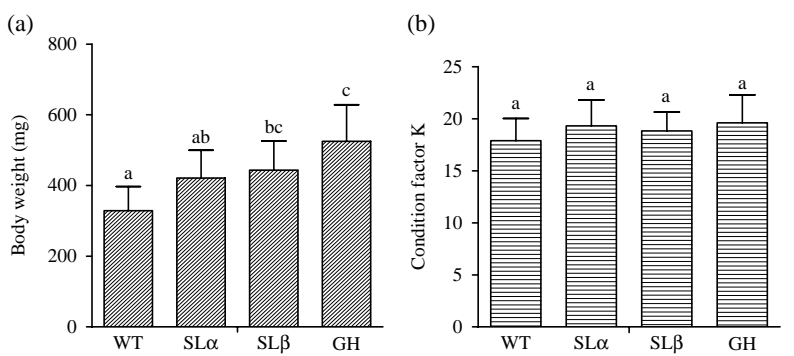

Figure 6 Body weight (a) and calculation of condition factor K (b) in 6-month-old zebrafish (Danio rerio) of transgenic zebrafish. WT, wild-type, non-transgenic fish; $\mathrm{S} L \alpha, \mathrm{S} L \alpha$-transgenic $\mathrm{G}_{0}$ fish; $\mathrm{S} L \beta$, $S L \beta$-transgenic $G_{0}$ fish; $G H$, GH-transgenic $G_{0}$ fish. Different letters indicate significant differences $(P<0.05)$ among the fish groups; $N=10$.

A similar result is found for the SL $\beta$-transgenic fish, with a $14 \cdot 5$-fold induction of SL $\beta$; however, only a $9 \cdot 81$-fold induction of $\mathrm{GH}$ is found in the GH-transgenic fish. The results indicate the successful overexpression of hormones in vivo, as anticipated.

Three types of IGF have been identified in zebrafish so far: IGF1, IGF2, and IGF3, with two subtypes of IGF2: IGF2a and IGF2b. Figure 8 shows the gene expression levels (fold induction over non-transgenic control) of IGFs in transgenic fish. The level of IGF1 was up-regulated by $5 \cdot 46$ - and 6.77-fold in the SL $\alpha$ transgenic and the SL $\beta$-transgenic fish respectively, whereas there was a sharp induction of $88 \cdot 34$-fold in the GH-transgenic fish as positive controls. The level of $I G F 2$ was also found to increase in the transgenic fish: $4 \cdot 38$-, $4 \cdot 35$-, and $11 \cdot 76$-fold for IGF2a and 2.83-, 3.94-, and $13 \cdot 40$-fold for $I G F 2 b$ in the SL $\alpha$-transgenic, SL $\beta$-transgenic, and GH-transgenic fish respectively. However, the amount of IGF3 decreased in the SL-transgenic fish $(0.57$-fold in the SL $\alpha$-transgenic and $0 \cdot 54$-fold in the SL $\beta$-transgenic ones), but showed an increase of $5 \cdot 41$-fold in the GH-transgenic fish.

Regarding energy metabolism, key marker genes, such as $L E P$, insulin (INS), PEPCK, SREBP, FAS, and ACC, were selected to understand the effect of SL on glucose synthesis and lipid metabolism. The two types of SREBP in zebrafish, SREBP1 and SREBP2, and only ACC2 were considered in this experiment. The expression levels of leptin, insulin, and PEPCK were found to demonstrate a 2.58-, 2.96-, and 1·32-fold increase in the SL $\alpha$-transgenic

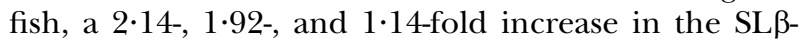
transgenic fish, and a 1.89-, 1.95-, and 5.42-fold increase in the GH-transgenic fish as positive controls (Fig. 9). It is interesting to discover that the expression level of $S R E B P 1$ was up-regulated $1 \cdot 51$ - and $1 \cdot 40$-fold and that of $S R E B P 2$ was down-regulated $0 \cdot 51$ - and $0 \cdot 53$-fold in the SL $\alpha$-transgenic and SL $\beta$-transgenic lines respectively. GH-transgenic fish demonstrated a 2-13-fold increase in $S R E B P 1$ expression and a 1.35-fold increase in SREBP2 expression. FAS expression increased $5 \cdot 10$ - and 2.81-fold, whereas ACC2 expression decreased 0.66and $0 \cdot 76$-fold in the SL $\alpha$-transgenic and SL $\beta$-transgenic lines respectively. GH-transgenic fish demonstrated a 4.82-fold increase in FAS mRNA level and a 3·41-fold increase in ACC2 mRNA level by comparison (Fig. 10).

VTG was selected to analyze the possible role of SLs in reproduction. It was found that $V T G$ mRNA was up-regulated in the SL $\alpha$-transgenic and SL $\beta$-transgenic fish with a 5.94- and 6.02-fold increase respectively over the control, and VTG mRNA was up-regulated in the GH-transgenic fish with a 2.04-fold increase (Fig. 11). POMC was chosen to understand the role of SLs in pigmentation, and a moderate increase of 2.53- and $2 \cdot 26$-fold was found in the SL $\alpha$-transgenic and SL $\beta$-transgenic fish respectively, but only $1 \cdot 45$-fold in the GH-transgenic fish (Fig. 12).

CAT and GST mRNA levels were used to investigate the effect of redundant SLs on the antioxidant defence system. CAT gene expression was found to decrease slightly in both the SL $\alpha$-transgenic $(0 \cdot 75$-fold) and the SL $\beta$-transgenic $(0 \cdot 82$-fold $)$ fish, but it was found to increase a little in the positive GH-transgenic fish (1·27-fold; Fig. 13). A moderate reduction in GST gene expression was observed in the SL $\alpha$-transgenic $(0 \cdot 55$ fold) and the SL $\beta$-transgenic $(0 \cdot 46$-fold $)$ fish, whereas almost no change was observed in the $\mathrm{GH}$-transgenic fish (Fig. 14).

\section{Discussion}

It is generally assumed that the direct microinjection of gene constructs into the pronucleus or nucleus of a fertilized egg before the onset of cleavage is the most effective way to incorporate new genetic material into

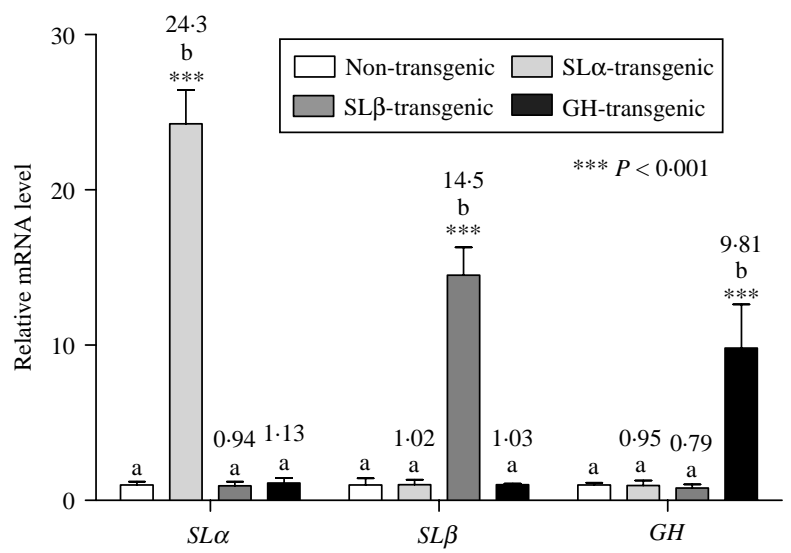

Figure 7 Gene expression of endogenous $S L \alpha, S L \beta$, and $G H$ in the SL $\alpha$-transgenic, SL $\beta$-transgenic, and GH-transgenic lines respectively. The hormones were successfully overexpressed without inducing or suppressing other members' levels in vivo. Each value represents the mean \pm s.D. of the three replicates. Different letters indicate significant differences $(P<0.05)$ from each other (one-way ANOVA). 


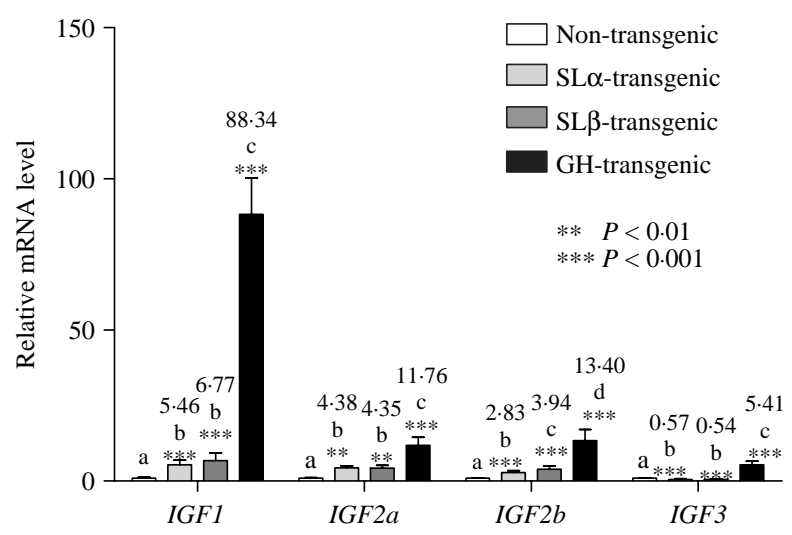

Figure 8 Insulin-like growth factor (IGF1, IGF2a, IGF2b, and IGF3) gene expression in the non-transgenic and different transgenic lines. Both SLs and GH induced different levels of IGFs in vivo. Each value represents the mean \pm s.D. of the three replicates. Different letters indicate significant differences $(P<0.05)$ from each other (one-way ANOVA).

the genome of injected embryos (Zhu et al. 1985, Ozato et al. 1986, Culp et al. 1991, Chen et al. 1993, Morales et al. 2001); however, the exact time of gene integration after microinjection is not guaranteed (Hamada et al. 1998, Figueiredo et al. 2007). Recently, the use of reporter genes that allow the evaluation of the degree of in vivo mosaicism in transgenic fish has facilitated the identification of probable germline founders (Rahman et al. 1997, 1998, Hamada et al. 1998, Ju et al. 1999, Liu et al. 2003), and the coinjection of a reporter transgene along with the gene construct of interest represents a considerable reduction in the effort needed to establish transgenic germlines (Rahman et al. 1997, 1998). The analysis of the GFP expression patterns permitted the selection of possible germline founders in the $\mathrm{G}_{0}$ generation. One week after microinjection, $66.5 \%$ (SL $\alpha)$ and $63 \%$ (SL $\beta)$ of the fish embryos expressed

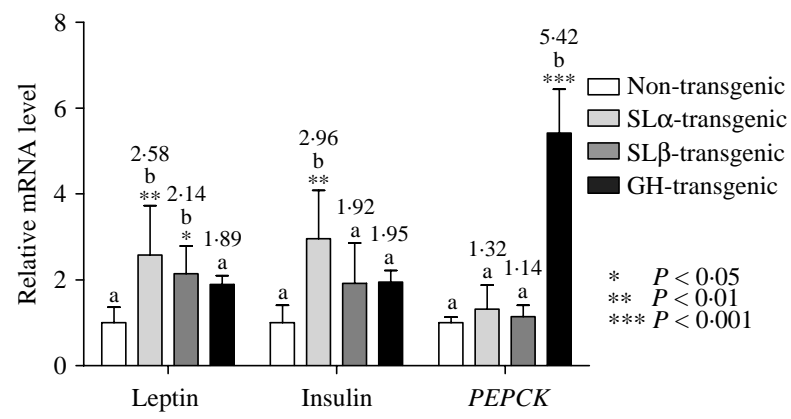

Figure 9 Leptin (LEP), insulin (INS), and phosphoenolpyruvate carboxykinase (PEPCK) gene expression in the non-transgenic and different transgenic lines. Both SLs and $\mathrm{GH}$ regulated the expression of $\angle E P$, INS, and PEPCK in different ways in vivo. Each value represents the mean \pm s.D. of the three replicates. Different letters indicate significant differences $(P<0.05)$ from each other (one-way ANOVA).

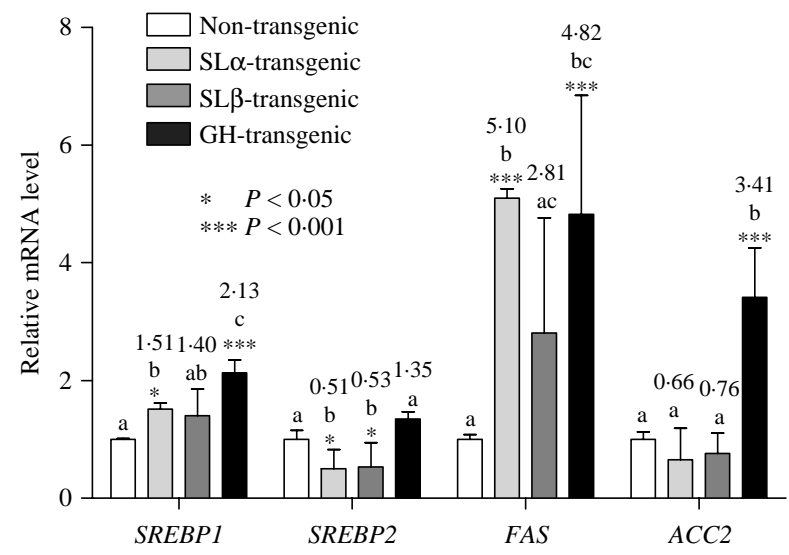

Figure 10 Sterol regulatory element binding protein (SREBP1 and $S R E B P 2)$, fatty acid synthase (FAS), and acetyl-CoA carboxylase 2 (ACC2) gene expression in the non-transgenic and different transgenic lines. Both SLs and $\mathrm{GH}$ regulated the expression of $S R E B P, F A S$, and $A C C$ in different ways in vivo. Each value represents the mean \pm s.D. of the three replicates. Different letters indicate significant differences $(P<0.05)$ from each other (one-way ANOVA).

GFP, indicating highly efficient transgenic fish production. However, part of this observed expression may be attributed to transitory expression due to the transcription of unintegrated transgenes (Chong \& Vielkind 1989, Thermes et al. 2002). However, as the DNA injected contained no plasmid DNA, the chance of DNA replication following embryogenesis was reduced. We found that $9 \cdot 7 \%(\mathrm{SL} \alpha)$ and $5 \cdot 5 \%$ (SL $\beta$ ) of the fish that we analyzed showed strong GFP reporter gene expression, similar to $5 \%$ of the fish with strong GFP expression reported by Gibbs \& Schmale (2000) for $\mathrm{G}_{0}$-transgenic zebrafish and $>3 \%$ of the fish with strong GFP expression reported by Gibbs \& Schmale (2000) and Thermes et al. (2002) for $\mathrm{G}_{0}$-transgenic medaka. Our conditions were similar to those of Gibbs \& Schmale (2000) and Thermes et al. (2002), who also used linearized transgenes in which GFP gene expression was under the control of ubiquitous promoters $(\alpha-$ or $\beta A)$.

In addition to genomic PCR confirmation, Southern blot analysis was used to reconfirm the GFP-positive transgenic fish. The probes designed in SL gene cDNA contained several introns in WT genomic DNA to avoid a false positive signal. After digestion with EcoRI, three different bands were detected in SL $\alpha$-transgenic $G_{0}$ sample \#116 and \#117, whereas only one band and two bands appeared in SL $\beta$-transgenic $\mathrm{G}_{0}$ sample \#103 and \#104 respectively. We used SmaI and XhoI to digest the whole genomic DNA to see whether the transgenes of total SL cDNA would be released, and the results showed only one band, as expected, but with different copies in the genomic DNA.

Measurement of the mRNA expression of SLs using real-time PCR revealed that the $z \beta A z S L \alpha$ and $z \beta A z S L \beta$ 


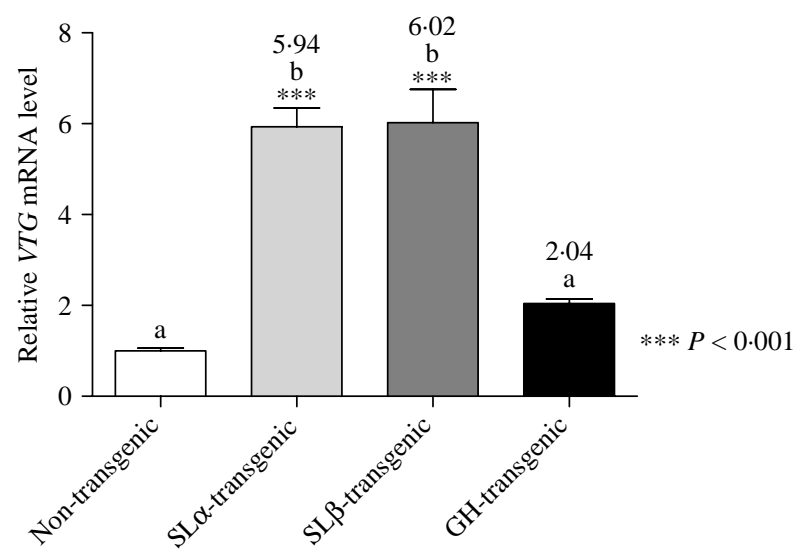

Figure 11 Vitellogenin (VTG) gene expression in the nontransgenic and different transgenic lines. Overexpressed SLS induced a higher level of VTG than did GH in the transgenic lines. Each value represents the mean \pm s.D. of the three replicates. Different letters indicate significant differences $(P<0.05)$ from each other (one-way ANOVA).

transgenes produced high levels of ubiquitous active hormone mRNAs, with an increase of $24 \cdot 3$-fold for SL $\alpha$ and $14 \cdot 5$-fold for SL $\beta$, compared with the nontransgenic controls, but without any increase in the $G H$ mRNA level. A primary function of $\mathrm{GH}$ is to promote somatic growth in fish; however, this function is accomplished indirectly through the GH/IGF1/IGF2 axis. This axis has been shown to play important roles in fish growth and development. After GH binds to the GHR in the target tissue and activates it, a tyrosine kinase called janus kinase $(J A K)$ is activated to transduce the GH signal in the target tissue to release IGF1 or IGF2 (Carter-Su \& Smit 1998). To find out whether SLs affect fish growth and development as GHs

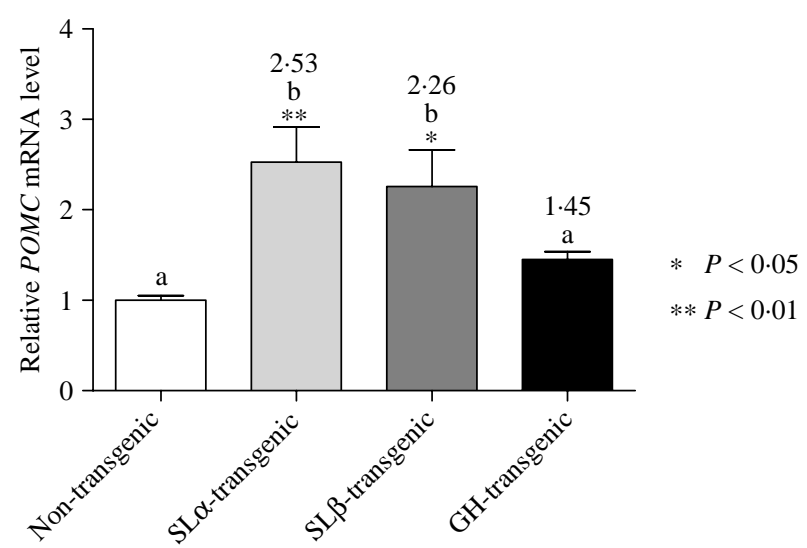

Figure 12 Proopiomelanocortin (POMC) gene expression in the non-transgenic and different transgenic lines. Both SLs and GH slightly regulated the expression of $P O M C$ in the transgenic lines. Each value represents the mean \pm s.D. of the three replicates. Different letters indicate significant differences $(P<0.05)$ from each other (one-way ANOVA).

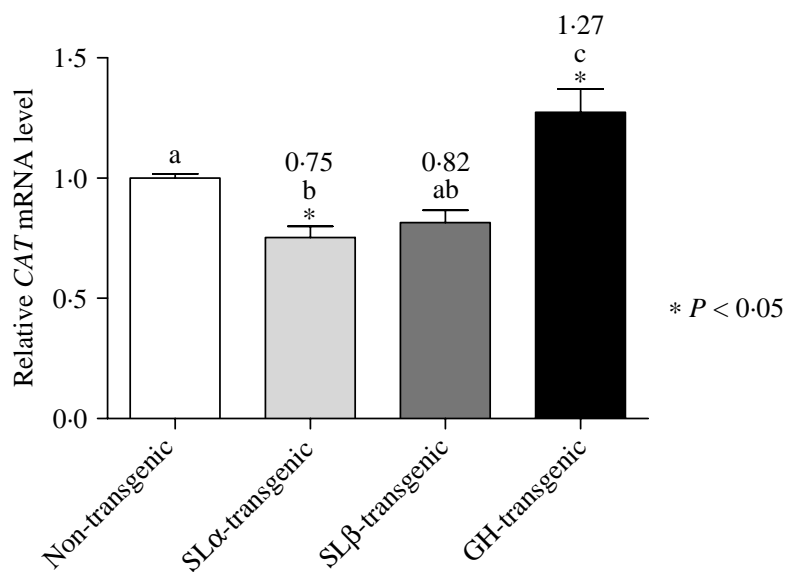

Figure 13 Catalase $(C A T)$ gene expression in the non-transgenic and different transgenic lines. Neither the SLs nor GH had any effect on the level of $C A T$. Each value represents the mean \pm s.D. of the three replicates. Different letters indicate significant differences $(P<0.05)$ from each other (one-way ANOVA).

are mediated by IGFs, the expression level of IGFs in SL-transgenic fish was investigated. In mammals, IGF1 plays an important role in both embryonic and postnatal growth (Baker et al. 1993), primarily through its stimulatory effects on cell proliferation and inhibition of cell death (apoptosis). Mice carrying null mutations in the IGF1 gene are born small and grow very poorly postnatally (Baker et al. 1993, Powell-Braxton et al. 1993, Liu et al. 1998). IGF2 is thought to be a primary growth factor required for early development, whereas IGF1 expression is required for achieving maximal growth (O'Dell \& Day 1998). In our in vivo study, a significant increase in IGF1 (5.46- and 6.77-fold), IGF2a (4.38- and $4 \cdot 35$-fold), and IGF2b (2.83- and 3.94-fold) in the SL $\alpha$-transgenic and the SL $\beta$-transgenic zebrafish larvae respectively brought about a moderate enhancement of zebrafish growth, with a respective 1.28- and 1.35-fold increase in body weight gain, by comparison with a $1 \cdot 65$-fold increase in the GH-transgenic zebrafish.

Our data agree with those of the transfer and overexpression of $G H$ transgenes from other groups, including salmonid (2-6-fold; Du et al. 1992), common carp (1·2-1·8-fold; Chen et al. 1993), zebrafish (2·6-fold; Figueiredo et al. 2007), and tilapia (3.5-4-fold; Rahman et al. 1998). SL $\alpha$ and SL $\beta$ could act on growth development to some extent as GH does - through IGF signaling. Recently, IGFs have been found to be expressed in teleosts in a wide range of tissues throughout life, which suggests that the autocrine/paracrine role of this hormone may be of particular physiological importance in bony fish (Schlueter et al. 2007, Sang et al. 2008, Wang et al. 2008). For example, gonad-specific IGF3 was found to be present only in the fish genome (Sang et al. 2008), which suggests its potential function in gonad development and 


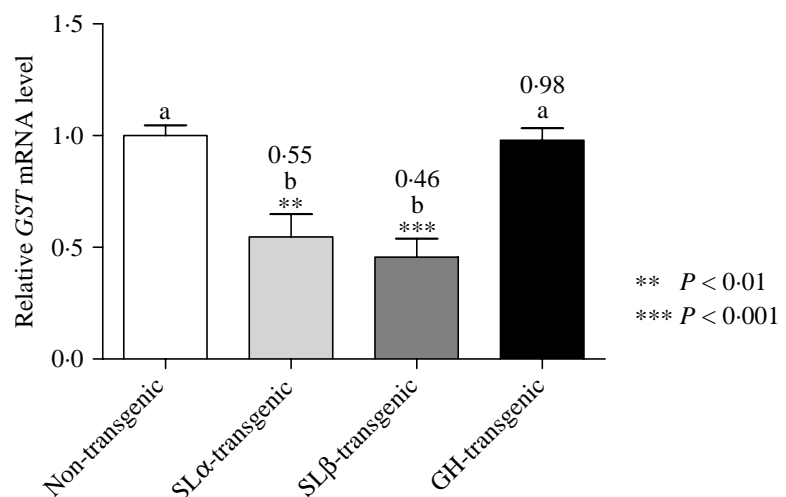

Figure 14 Glutathione $S$-transferase (GST) gene expression in the non-transgenic and different transgenic lines. SLs reduced the expression of GST, whereas GH had no effect on it. Each value represents the mean \pm S.D. of the three replicates. Different letters indicate significant differences $(P<0.05)$ from each other (one-way ANOVA).

reproduction in teleosts. IGFs have also been found to be required for primordial germ cell migration and survival (Mommsen \& Plisetskaya 1991, Papasani et al. 2006). However, SLs did not appear to enhance IGF3 gene expression in this study.

Glucose is stored as glycogen in the liver and muscle (Wang et al. 1994, Elo et al. 2007). PEPCK is an indicator of blood glucose levels for the examination of glucose metabolism, which catalyzes a rate-limiting step in gluconeogenesis, and is transcriptionally regulated by glucagon and insulin (Brown \& Goldstein 1997). Our study showed that the overexpression of SL $\alpha$ could induce more mRNAs of insulin (2.96-fold), and thus PEPCK (1·32-fold), than SL $\beta$ could (insulin: 1.92-fold; PEPCK: 1-14-fold). SREBP can up-regulate the synthesis of enzymes involved in sterol biosynthesis. For instance, SREBP1 regulates the genes needed to make fatty acids, while SREBP2 regulates the genes involved in cholesterol metabolism (Company et al. 1999, Brownsey et al. 2006). The overexpression of both SL $\alpha$ and SL $\beta$ increased SREBP1 expression but inhibited SREBP2 expression in zebrafish. The abundant $\mathrm{SL} \alpha$ resulted in more fatty acids through activation of a higher level of FAS expression than did SL $\beta$ (Fig. 10). A transient increase in plasma SL levels was found in short-term fasted fish (Vega-Rubin de Celis et al. 2003), which suggests that SL may play a role as an anti-obesity hormone helping to expedite growth and reproductive processes following the replenishment of fat stores, and/or mediate the adaptation to fasting until the lipolytic action of GH and/or other endocrine factors is fully accomplished. This is consistent with the inhibition of ACC expression in SL-transgenic fish, in which the fatty mechanism is regulated by the inhibition of the $\beta$-oxidation of the fatty acid in mitochondria, as the presence of fatty acids inhibits its activities (Sahu 2003).
A similar result was also found in European sea bass (Johnson et al. 1997). Leptin plays a key role in regulating energy intake and energy expenditure, including appetite and metabolism (Mayer et al. 1998). A moderate induction (2.58- and $2 \cdot 14$-fold) of $L E P$ in SL $\alpha$-transgenic and SL $\beta$-transgenic fish helps to execute anti-obesity effects.

However, studies of seasonal changes in $S L$ mRNA showed the gradual stimulation of SL synthesis and release during sexual maturation, and spawning females tend to have more SL cells than equivalent males, indicating that SL may play a role in the control of some steps of reproduction (Planas et al. 1992, Rand-Weaver et al. 1992, Oliverau \& Rand-Weaver 1994). Plasma SL concentrations were found to remain relatively constant throughout gonad development but were found to drop during or following ovulation in sole and halibut (Schneider 1996). SL was found to stimulate gonad steroidogenesis produced by testicular fragments and ovarian follicles in vitro in coho salmon; however, this steroidogenic activity was considerably less than that of GH (Planas et al. 1992). SL synthesis and release were found to be inhibited by gonadectomy (Specker \& Sullivan 1994). VTG is an egg yolk precursor protein crucial for reproductive success, such as oocyte growth, oocyte maturation, early embryogenesis, and later, larval development (Nguyen et al. 2006). Our study showed that the ectopic expression of SL $\alpha$ and SL $\beta$ in vivo significantly induced the mRNA expression of $V T G$, indicating that SLs play a role in vitellogenesis. The stimulation and secretion of VTG might pass through the granulose and thecal cell layers, bind to specific receptors on the oocyte surface, and are sequestered via receptor-mediated endocytosis (Schallreuter et al. 2008).

SL has also been found to be related to pigmentation, melanosome aggregation, chromatophore proliferation, and morphogenesis. A medaka (O. latipes) $c i$ mutant in which the proliferation and morphogenesis of chromatophore pigment cells are deficient was recently found to have $S L$ gene mutation (Fukamachi et al. 2006). An increased number and more dendritically shaped leucophores were observed, and fewer xanthophores were visible in the mutant, so the body of the WT was darker than that of the ci mutant (Fukamachi et al. 2006). The effect of SL on melanosome aggregation was studied in red drum (Zhu \& Thomas 1997) and zebrafish (Castrucci et al. 1997) in a dose-dependent manner. A $c i-l f$ double mutant (ci and lacking leucophores) was used to investigate the role of SL in the regulation of body color, and the results showed that the lf gene played an indispensable role in leucophore development of epistatic to SL signaling (Fukamachi et al. 2006). In the present study, the POMC gene was used to study the effect of SL on pigmentation. A twofold induction of $P O M C$ was found in both the 
SL $\alpha$-transgenic and the SL $\beta$-transgenic zebrafish larvae, indicating the role of SL in body color and background adaptation. POMC (expressing melanocyte-stimulating hormone) can stimulate the production and release of melanin (melanogenesis) by melanocytes in the skin (Brown-Borg \& Rakoczy 2005, Brown-Borg et al. 2005). An interesting disrupted stripe phenotype was found only in the SL $\alpha$-transgenic fish (Fig. 5). The molecular mechanism of SL $\alpha$ in stripe morphogenesis in fish remains to be investigated.

$\mathrm{GH}$ is a key player in the physiological mechanisms of altered stress resistance, such as the alteration in the activity of multiple enzymatic components of methionine and glutathione metabolism in Ames dwarf mice (Brown-Borg et al. 2009). Studies show that Ames dwarf mice live significantly longer than their WT siblings and exhibit elevated antioxidative defences and reduced oxidative damage, perhaps leading to their extended longevity (Chelikani et al. 2004, Leggatt et al. 2007). Research into GH-transgenic salmon shows the up-regulation of the components of the glutathione antioxidant system to combat potentially higher reactive oxygen species production, based on the accelerated growth and increased metabolic rates. We, however, found slight reductions in the expression of the catalase (CAT) gene and GST gene in both the SL $\alpha$-transgenic and the SL $\beta$-transgenic fish. Catalase is a common central enzyme involved in reactive oxygen species (ROS) scavenging through the degradation of hydrogen peroxide into oxygen and water (Chelikani et al. 2004). GSTs involved in xenobiotic metabolism are cytosolic proteins that catalyze the conjugation of glutathione with a substrate bearing an electrophilic atom. Free reactive electrophilic intermediates of xenobiotics can produce damage to important cellular constituents. The decreases in these two key enzymes in the antioxidant defence system in the SL-transgenic fish suggest a reduction in the capability to deal with an oxidative stress situation (Leggatt et al. 2003). An increased growth rate in transgenic zebrafish was found to be associated with an increased metabolic rate (Rosa et al. 2008). It is expected that the antioxidant system in GH-transgenic fish might be up-regulated to cope with increased ROS production based on the high metabolic demand due to accelerated growth rate in these transgenic fish. The glutathione antioxidant system was found to be enhanced in GH-transgenic coho salmon (Leggatt et al. 2003); however, a resistance effect to excess $\mathrm{GH}$ caused a decrease in the catalytic subunit expression of glutamate-cysteine ligase, an enzyme responsible for glutathione synthesis, in GH-transgenic zebrafish (Rosa et al. 2008). The reduction in the efficiency of the antioxidant defence system due to the overexpression of SLs may result in the greater susceptibility of SL-overexpressing fish to oxidative stress, and such altered stress capacity may affect their health and life span.

In summary, we have successfully generated transgenic zebrafish with the ectopic expression of SL $\alpha$ and SL $\beta$ of zebrafish in vivo using the coinjection strategy. The data obtained here indicate that the overexpression of SLs can induce IGFs, but that the level of induction is well below that of $\mathrm{GH}$; however, overexpressing SLs could affect growth, development, glucose synthesis, lipid metabolism, reproduction, pigmentation, and the antioxidant defence system. Whether these observed effects were mediated via GHRs or SLR remain to be investigated. To find out the full pictures of the actions of SLs on growth and metabolisms, adult transgenic fish should be employed for further investigations.

\section{Declaration of interest}

The authors declare that there is no conflict of interest that could be perceived as prejudicing the impartiality of the research reported.

\section{Funding}

This research did not receive any specific grant from any funding agency in the public, commercial, or not-for-profit sector, all equipments used are already available in the Department of Biochemistry, and consumables were paid by research allowance from the Department of Biochemistry, Chinese University.

\section{Acknowledgements}

The authors thank the graduate division of Biochemistry (Science) for the provision of a post-graduate studentship to GW and the Department of Biochemistry for its support of this research with a high degree of academic freedom.

\section{References}

Ain R, Dai G, Dunmore JH, Godwin AR \& Soares MJ 2004 A prolactin family paralog regulates reproductive adaptations to a physiological stressor. PNAS 101 16543-16548. (doi:10.1073/pnas.0406185101)

Baker J, Liu JP, Robertson EJ \& Efstratiadis A 1993 Role of insulin-like growth factors in embryonic and postnatal growth. Cell 75 73-82. (doi:10.1016/S0092-8674(05)80085-6)

Benedet S, Bjornsson BT, Taranger GL \& Andersson E 2008 Cloning of somatolactin alpha, beta forms and the somatolactin receptor in Atlantic salmon: seasonal expression profile in pituitary and ovary of maturing female broodstock. Reproductive Biology and Endocrinology 6 42. (doi:10.1186/1477-7827-6-42)

Brown MS \& Goldstein JL 1997 The SREBP pathway: regulation of cholesterol metabolism by proteolysis of a membrane-bound transcription factor. Cell 89 331-340. (doi:10.1016/S00928674(00)80213-5)

Brown-Borg HM \& Rakoczy SG 2005 Glutathione metabolism in longliving Ames dwarf mice. Experimental Gerontology 40 115-120. (doi:10.1016/j.exger.2004.11.004) 
Brown-Borg HM, Rakoczy SG \& Uthus EO 2005 Growth hormone alters methionine and glutathione metabolism in Ames dwarf mice. Mechanisms of Ageing and Development 126 389-398. (doi:10.1016/ j.mad.2004.09.005)

Brown-Borg HM, Rakoczy SG, Sharma S \& Bartke A 2009 Long-living growth hormone receptor knockout mice: potential mechanisms of altered stress resistance. Experimental Gerontology 44 10-19. (doi:10.1016/j.exger.2008.07.002)

Brownsey RW, Boone AN, Elliott JE, Kulpa JE \& Lee WM 2006 Regulation of acetyl-CoA carboxylase. Biochemical Society Transactions 34 223-227. (doi:10.1042/BST20060223)

Calduch-Giner JA, Pendon C, Valdivia MM \& Perez-Sanchez J 1998 Recombinant somatolactin as a stable and bioactive protein in a cell culture bioassay: development and validation of a sensitive and reproducible radioimmunoassay. Journal of Endocrinology 156 441-447. (doi:10.1677/joe.0.1560441)

Carter-Su C \& Smit LS 1998 Signaling via JAK tyrosine kinases: growth hormone receptor as a model system. Recent Progress in Hormone Research 53 61-82.

Castrucci AM, Almeida AL, al-Obeidi FA, Hadley ME, Hruby VJ, Staples DJ \& Sawyer TK 1997 Comparative biological activities of $\alpha$-MSH antagonists in vertebrate pigment cells. General and Comparative Endocrinology 105 410-416. (doi:10.1006/gcen.1996.6844)

Chelikani P, Fita I \& Loewen PC 2004 Diversity of structures and properties among catalases. Cellular and Molecular Life Sciences 61 192-208. (doi:10.1007/s00018-003-3206-5)

Chen TT, Kight K, Lin CM, Powers DA, Hayat M, Chatakondi N, Ramboux AC, Duncan PL \& Dunham RA 1993 Expression and inheritance of RSVLTR-rtGH1 complementary DNA in the transgenic common carp, Cyprinus carpio. Molecular Marine Biology and Biotechnology 2 88-95.

Chen TT, Marsh A, Shamblott M, Chan KM, Tang YL, Cheng CM \& Yang BY 1994 Structure and evolution of fish growth hormone and insulin-like growth factor genes. In Fish Physiology, vol 13, Molecular Aspect of Hormonal Regulation in Fish, pp 179-209. Eds CL Hew \& N Sherwood. New York: Academic Press.

Chong SSC \& Vielkind JR 1989 Expression and fate of CAT reporter gene microinjected into fertilized medaka (Oryzias latipes) eggs in the form of plasmid DNA, recombinant phage particles and its DNA tag. Theoretical and Applied Genetics 78 369-380. (doi:10.1007/ BF00265299)

Company R, Calduch-Giner JA, Pérez-Sánchez J \& Kaushik SJ 1999 Protein sparing effect of dietary lipids in common dentex (Dentex dentex): a comparative study with sea bream (Sparus aurata) and sea bass (Dicentrarchus labrax). Aquatic Living Resources 12 23-30. (doi:10. 1016/S0990-7440 (99)80011-4)

Culp P, Nusslein-Volhard C \& Hopkins N 1991 High-frequency germline transmission of plasmid DNA sequences injected into fertilized zebrafish eggs. PNAS 88 7953-7957. (doi:10.1073/pnas.88.18.7953)

Du SJ, Gong ZY, Fletcher GL, Shears MA, King MJ, Idler DR \& Hew CL 1992 Growth enhancement in transgenic Atlantic salmon by the use of an "all fish" chimeric growth hormone gene construct. Marine Biotechnology 10 176-181. (doi:10.1038/nbt0292-176)

Elo B, Villano CM, Govorko D \& White LA 2007 Larval zebrafish as a model for glucose metabolism: expression of phosphoenolpyruvate carboxykinase as a marker for exposure to anti-diabetic compounds. Journal of Molecular Endocrinology 38 433-440. (doi:10. 1677/JME-06-0037)

Figueiredo Md A, Lanes CFC, Almeida DV \& Marins LF 2007 Improving the production of transgenic fish germlines: in vivo evaluation of mosaicism in zebrafish (Danio rerio) using a green fluorescent protein (GFP) and growth hormone cDNA transgene co-injection strategy. Genetics and Molecular Biology 30 31-36. (doi:10. 1590/S1415-47572007000100008)

Fukamachi S \& Meyer A 2007 Evolution of receptors for growth hormone and somatolactin in fish and land vertebrates: lessons from the lungfish and sturgeon orthologues. Journal of Molecular Evolution 65 359-372. (doi:10.1007/s00239-007-9035-7)
Fukamachi S, Sugimoto M, Mitani H \& Shima A 2004 Somatolactin selectively regulates proliferation and morphogenesis of neuralcrest derived pigment cells in medaka. PNAS 101 10661-10666. (doi:10.1073/pnas.0401278101)

Fukamachi S, Yada T \& Mitani H 2005 Medaka receptors for SL and growth hormone: phylogenetic paradox among fish growth hormone receptors. Genetics 171 1875-1883. (doi:10.1534/genetics. 105.048819)

Fukamachi S, Wakamatsu Y \& Mitani H 2006 Medaka double mutants for color interfere and leucophore free: characterization of the xanthophore-somatolactin relationship using the leucophore free gene. Development Genes and Evolution 216 152-157. (doi:10.1007/ s00427-005-0040-9)

Fukamachi S, Yada T, Meyer A \& Kinoshita M 2009 Effects of constitutive expression of SL $\alpha$ on skin pigmentation in medaka. Gene 442 81-87. (doi:10.1016/j.gene.2009.04.010)

Gibbs PD \& Schmale MC 2000 GFP as a genetic marker scorable throughout the life cycle of transgenic zebra fish. Marine Biotechnology 2 107-125. (doi:10.1007/s101269900014)

Green JA 2004 Defining the function of a prolactin gene family member. PNAS 101 16397-16398. (doi:10.1073/pnas.0406934101)

Hamada K, Tamaki K, Sasado T, Watai Y, Kani S, Wakamatsu Y, Ozato K, Kinoshita M, Kohno R, Takagi S et al. 1998 Usefulness of the medaka $\beta$-actin promoter investigated using a mutant GFP reporter gene in transgenic medaka (Oryzias latipes). Molecular Marine Biology and Biotechnology 7 173-180.

Jiang Q, Ko WK, Lerner EA, Chan KM \& Wong AO 2008 Grass carp somatolactin: I. Evidence for PACAP induction of somatolactin- $\alpha$ and $-\beta$ gene expression via activation of pituitary PAC-I receptors. American Journal of Physiology. Endocrinology and Metabolism 295 E463-E476. (doi:10.1152/ajpendo.90385.2008)

Jiao B, Huang X, Chan CB, Zhang L, Wang D \& Cheng CH 2006 The co-existence of two growth hormone receptors in teleost fish and their differential signal transduction, tissue distribution and hormonal regulation of expression in seabream. Journal of Molecular Endocrinology 36 23-40. (doi:10.1677/jme.1.01945)

Johnson LL, Norberg B, Willis ML, Zebroski H \& Swanson P 1997 Isolation, characterization, and radioimmunoassay of Atlantic halibut somatolactin and plasma levels during stress and reproduction in flatfish. General and Comparative Endocrinology 105 194-209. (doi:10.1006/gcen.1996.6821)

Ju B, Xu Y, He J, Liao J, Yan T, Hew CL, Lam TJ \& Gong Z 1999 Faithful expression of green fluorescent protein (GFP) in transgenic zebrafish embryos under control of zebrafish gene promoters. Developmental Genetics 25 158-167. (doi:10.1002/(SICI) 1520-6408 (1999) 25:2 < 158::AID-DVG10>3.0.CO;2-6)

Kakizawa S, Kaneko T, Hasegawa S \& Hirano T 1995 Effects of feeding, fasting, background adaptation, acute stress, and exhaustive exercise on the plasma somatolactin concentrations in rainbow trout. General and Comparative Endocrinology 98 137-146. (doi:10. 1006/gcen.1995.1054)

Kakizawa S, Kaneko T \& Hirano T 1996 Elevation of plasma somatolactin concentrations during acidosis in rainbow trout (Oncorhynchus mykiss). Journal of Experimental Biology 199 1043-1051.

Kaneko T 1996 Cell biology of somatolactin. International Review of Cytology 169 1-24. (doi:10.1016/S0074-7696(08)61983-X)

Leggatt RA, Devlin RH, Farrell AP \& Randall DJ 2003 Oxygen uptake of growth hormone transgenic coho salmon during starvation and feeding. Journal of Fish Biology 62 1053-1066. (doi:10.1046/j.10958649.2003.00096.x)

Leggatt RA, Brauner CJ, Iwama GK \& Devlin RH 2007 The glutathione antioxidant system is enhanced in growth hormone transgenic coho salmon (Oncorhynchus kisutch). Journal of Comparative Physiology B 177 413-422. (doi:10.1007/s00360-006-0140-5)

Liu ZJ, Moav B, Faras AJ, Guise KS, Kapuscinski AR \& Hackett PB 1990 Functional analysis of elements affecting expression of the $\beta$-actin gene of carp. Molecular and Cellular Biology 10 3432-3440. 
Liu ZJ, Moav B, Faras AJ, Guise KS, Kapuscinski AR \& Hackett P 1991 Importance of the CArG box in regulation of $\beta$-actinencoding genes. Gene 108 211-217. (doi:10.1016/0378-1119(91) 90436-F)

Liu JL, Grinberg A, Westphal H, Sauer B, Accili D, Karas M \& LeRoith D 1998 Insulin-like growth factor-I affects perinatal lethality and postnatal development in a gene dosage-dependent manner: manipulation using the Cre/loxP system in transgenic mice. Molecular Endocrinology 12 1452-1462. (doi:10.1210/me.12.9.1452)

Liu NA, Huang H, Yang Z, Herzog W, Hammerschmidt M, Lin S \& Melmed S 2003 Pituitary corticotroph ontogeny and regulation in transgenic zebrafish. Molecular Endocrinology 17 959-966. (doi:10. $1210 /$ me.2002-0392)

Mayer I, Rand-Weaver M \& Borg B 1998 Effects of gonadectomy and steroids on plasma and pituitary levels of somatolactin in Atlantic salmon, Salmo salar. General and Comparative Endocrinology 109 223-231. (doi:10.1006/gcen.1997.7015)

Mommsen TP \& Plisetskaya EM 1991 Insulin in fishes and agnathans: history, structure and metabolic regulation. Reviews in Aquatic Sciences 4 225-259.

Morales R, Herrera MT, Arenal A, Cruz A, Hernández O, Pimentel R, Guillén I, Martínez R \& Estrada MP 2001 Tilapia chromosomal growth hormone gene expression accelerates growth in transgenic zebrafish (Danio rerio). Electronic Journal of Biotechnology 14 1-7.

Nguyen N, Sugimoto M \& Zhu Y 2006 Production and purification of recombinant somatolactin $\beta$ and its effects on melanosome aggregation in zebrafish. General and Comparative Endocrinology 145 182-187. (doi:10.1016/j.ygcen.2005.09.015)

O'Dell SD \& Day IN 1998 Insulin-like growth factor II (IGF-II). International Journal of Biochemistry and Cell Biology 30 767-771. (doi:10.1016/S1357-2725(98)00048-X)

Olivereau M \& Rand-Weaver M 1994 Immunocytochemical study of the somatolactin cells in the pituitary of Pacific salmon,

Oncorhynchus nerka, and $O$. keta at some stages of the reproductive cycle. General and Comparative Endocrinology 93 28-35. (doi:10.1006/ gcen.1994.1004)

Ono M, Takayama Y, Rand-Weaver M, Sakata S, Yasunaga T, Noso T \& Kawauchi H 1990 cDNA cloning of somatolactin, a pituitary protein related to growth hormone and prolactin. PNAS 87 4330-4334. (doi:10.1073/pnas.87.11.4330)

Ozato K, Kondoh H, Inohara H, Iwamatsu T, Wakamatsu Y \& Okada TS 1986 Production of transgenic fish: introduction and expression of chicken delta-crystallin gene in medaka embryos. Cell Differentiation 19 237-244. (doi:10.1016/0045-6039(86)90100-4)

Papasani MR, Robison BD, Hardy RW \& Hill RA 2006 Early developmental expression of two insulins in zebrafish (Danio rerio). Physiological Genomics 27 79-85. (doi:10.1152/physiolgenomics. 00012.2006)

Pierce AL, Fox BK, Davis LK, Visitacion N, Kitahashi T, Hirano T \& Grau EG 2007 Prolactin receptor, growth hormone receptor, and putative somatolactin receptor in Mozambique tilapia: tissue specific expression and differential regulation by salinity and fasting. General and Comparative Endocrinology 154 31-40. (doi:10. 1016/j.ygcen.2007.06.023)

Planas JV, Swanson P, Rand-Weaver M \& Dickhoff WW 1992 Somatolactin stimulates in vitro gonadal steroidogenesis in coho salmon, Oncorhynchus kisutch. General and Comparative Endocrinology 87 1-5. (doi:10.1016/0016-6480(92)90142-7)

Powell-Braxton L, Hollingshead P, Warburton C, Dowd M, Pitts-Meek S, Dalton D, Gillett N \& Stewart TA 1993 IGF-I is required for normal embryonic growth in mice. Genes and Development 7 2609-2617. (doi:10.1101/gad.7.12b.2609)

Rahman MA, Iyengar A \& Maclean N 1997 Co-injection strategy improves integration efficiency of a growth hormone gene construct, resulting in lines of transgenic tilapia (Oreochromis niloticus) expressing an exogenous growth hormone gene. Transgenic Research 6 369-378. (doi:10.1023/A:1018479232761)
Rahman MA, Mak R, Ayad H, Smith A \& Maclean N 1998 Expression of a novel piscine growth hormone gene results in growth enhancement in transgenic tilapia (Oreochromis niloticus). Transgenic Research 7 357-369. (doi:10.1023/A:1008837105299)

Rand-Weaver M, Noso T, Muramoto K \& Kawauchi H 1991 Isolation and characterization of somatolactin, a new protein related to growth hormone and prolactin from Atlantic cod (Gadus morhua) pituitary glands. Biochemistry 30 1509-1515. (doi:10.1021/ bi00220a010)

Rand-Weaver M, Swanson P, Kawauchi H \& Dickhoff WW 1992 Somatolactin, a novel pituitary protein: purification and plasma levels during reproductive maturation of coho salmon. Journal of Endocrinology 133 393-403. (doi:10.1677/joe.0.1330393)

Rand-Weaver M, Pottinger TG \& Sumpter JP 1993 Plasma somatolactin concentrations in salmonid fish are elevated by stress. Journal of Endocrinology 138 509-515. (doi:10.1677/joe.0.1380509)

Rosa CE, Figueiredo MA, Lanes CF, Almeida DV, Monserrat JM \& Marins LF 2008 Metabolic rate and reactive oxygen species production in different genotypes of GH-transgenic zebrafish. Comparative Biochemistry and Physiology. Part B, Biochemistry Eै Molecular Biology 149 209-214. (doi:10.1016/j. cbpb.2007.09.010)

Sahu A 2003 Leptin signaling in the hypothalamus: emphasis on energy homeostasis and leptin resistance. Frontiers in Neuroendocrinology 24 225-253. (doi:10.1016/j.yfrne.2003.10.001)

Sang X, Curran MS \& Wood AW 2008 Paracrine insulin-like growth factor signaling influences primordial germ cell migration: in vivo evidence from the zebrafish model. Endocrinology 149 5035-5042. (doi:10.1210/en.2008-0534)

Schallreuter KU, Kothari S, Chavan B \& Spencer JD 2008 Regulation of melanogenesis - controversies and new concepts. Experimental Dermatology 17 395-404. (doi:10.1111/j.1600-0625. 2007.00675.x)

Schlueter PJ, Sang X, Duan C \& Wood AW 2007 Insulin-like growth factor receptor $1 b$ is required for zebrafish primordial germ cell migration and survival. Developmental Biology 305 377-387. (doi:10. 1016/j.ydbio.2007.02.015)

Schneider WJ 1996 Vitellogenin receptors: oocyte-specific members of the low-density lipoprotein receptor supergene family. International Review of Cytology 166 103-137. (doi:10.1016/S00747696(08)62507-3)

Specker JL \& Sullivan CV 1994 Vitellogenesis in fishes: status and perspectives. In Perspectives in Comparative Endocrinology, pp 59-63. Eds KG Davey, RE Peter \& SS Tobe. Ottawa, ON: National Research Council of Canada.

Thermes V, Grabher C, Ristoratore F, Bourrat F, Choulika A, Wittbrodt J \& Joly JS 2002 I-SceI meganuclease mediates highly efficient transgenesis in fish. Mechanisms of Development 118 91-98. (doi:10.1016/S0925-4773(02)00218-6)

Vega-Rubin de Celis S, Gomez P, Calduch-Giner JA, Medale F \& PerezSanchez J 2003 Expression and characterization of European sea bass (Dicentrarchus labrax) somatolactin: assessment of in vivo metabolic effects. Marine Biotechnology 5 92-101. (doi:10.1007/ s10126-002-0053-6)

Wan G, Jiang Q, Wong AOL \& Chan KM 2009 Novel component of the pituitary-hepatic axis: functional interaction between somatolactin and insulin-like growth factor. In The Second International Symposium for Fish Growth and Reproduction. Satellite Symposium for 16th International Congress of Comparative Endocrinology, The University of Hong Kong, June 20-21, 2009. Abs \#: 5-3.

Wang X, Sato R, Brown MS, Hua X \& Goldstein JL 1994 SREBP-1, a membrane-bound transcription factor released by sterolregulated proteolysis. Cell 77 53-62. (doi:10.1016/0092-8674 (94) 90234-8)

Wang DS, Jiao B, Hu C, Huang X, Liu Z \& Cheng CH 2008 Discovery of a gonad-specific IGF subtype in teleost. Biochemical and Biophysical Research Communications 367 336-341. (doi:10.1016/j.bbrc.2007.12.136) 
Westerfield M 1995 The Zebrafish Book: A Guide for the Laboratory Use of Zebrafish (Danio rerio), 3rd edn, ch 1-3. Eugene, OR: University of Oregon Press.

Yang BY \& Chen TT 2003 Identification of a new growth hormone family protein, somatolactin-like protein, in the rainbow trout (Oncorhyncus mykiss) pituitary gland. Endocrinology 144 850-857. (doi:10.1210/en.2002-221005)

Zhu Y \& Thomas P 1995 Red drum somatolactin: development of a homologous radioimmunoassay and plasma levels after exposure to stressors or various backgrounds. General and Comparative Endocrinology 99 275-288. (doi:10.1006/gcen.1995.1111)

Zhu Y \& Thomas P 1996 Elevations of somatolactin in plasma and pituitaries and increased $\alpha$-MSH cell activity in red drum exposed to black background and decreased illumination. General and Comparative Endocrinology 101 21-31.

Zhu Y \& Thomas P 1997 Effects of somatolactin on melanosome aggregation in the melanophores of red drum (Sciaenops ocellatus) scales. General and Comparative Endocrinology 105 127-133. (doi:10. 1006/gcen.1996.6810)
Zhu Z, He L \& Chen S 1985 Novel gene transfer into the fertilized eggs of goldfish (Carassius auratus L.1758). Zeitschrift für Angewandte Ichthyologie 1 31-34. (doi:10.1111/j.1439-0426.1985. tb00408.x)

Zhu Y, Stiller JW, Shaner MP, Baldini A, Scemama JL \& Capehart AA 2004 Cloning of somatolactin alpha and beta cDNAs in zebrafish and phylogenetic analysis of two distinct somatolactin subtypes in fish. Journal of Endocrinology 182 509-518. (doi:10.1677/joe.0. 1820509)

Zhu Y, Song D, Tran NT \& Nguyen N 2007 The effects of the members of growth hormone family knockdown in zebrafish development. General and Comparative Endocrinology 150 395-404. (doi:10.1016/j. ygcen.2006.10.009)

Received in final form 4 August 2010

Accepted 26 August 2010

Made available online as an Accepted Preprint 26 August 2010 